Metric Propaganda in Canada.-The Daily Consular and Trade Reports for March 16 contains a brief statement by Consul Seyfert of Stratford, of the active movement now in progress in Canada, in favor of the Metric System. He says:

"With a view of adopting the metric system in weights and measures at an early day the Canadian government is preparing and educating the people for the change. Prof. J. C. McLennan, of the University of Toronto, has been engaged by the Dominion government to devote the next year to explaining the system in a series of lectures in all the Ieading cities from Halifax to Vancouver. The professor delivered his first lecture on the subject at Stratford, February 7 , before the board of trade. According to his explanation it is the object of the Canadian government to secure a.uniform standard of weights and measures throughout the entire British Empire, and thus to advance trade relations among the different colonies of the Empire. The board of trade at Stratford unanimously adopted resolutions, urging adoption of the system."

Thus is being demonstrated month by month the world-wide movement in favor of educational and intellectual, no less than of moral and social reform.

R. P. W.

\title{
THE ARTIFICIAL INDUCTION OF LEAF FORMATION IN THE OCOTILLO.
}

\section{BY F. E. LLOYD.}

The Ocotillo is a desert plant which during the dry season bears no foliage leaves, following the first rains its thorny branches soon become covered with new leaves. The author of this article thought "that it would be instructive to see if any light could be obtained upon the influence of metoric water upon the development of leaves." Bandaging a portion of a branch with cheese cloth which was so connected with a reservoir of water in a bottle that it remained constantly moist. In three days leaves began to appear below the bandage for 12 to 15 inches. In case of this experiment the leaves did not grow so rapidly as they do when growing following a rain.-Plant World, March, 1906.

The Chemistry Teachers Club of New York City has undertaken a most practical and unique method of improving and enriching the course in chemistry in the New York High Schools. Each member sends to a committee any new idea or improvement in apparatus, or new ways of performing an experiment.

The committee selects such as are considered worthy of preservation. These are printed on cards of a suitable size for a filing case and a set furnished to each member of the Club.

The actual work of printing is done by one of the members, Mr. Henry $T$. Weed of the Manual Training High School, Brooklyn.

The Club has voted to give a set of these cards as they appear to School ScIence aNd Mathematics. Selections from them will be printed in future numbers. 